Vol. 17 (2008): 153-164.

\title{
Effect of Cirsium arvense L. on soil physical properties and crop growth
}

Endla Reintam, Katrin Trükmann, Jaan Kuht, Avo Toomsoo, Triin Teesalu, Tiina Köster Estonian University of Life Sciences, Institute of Agricultural and Environmental Sciences, Kreutzwaldi 1a, 51014 Tartu, Estonia, email: endla.reintam@emu.ee

Liina Edesi, Edvin Nugis

Estonian Research Institute of Agriculture, Teaduse 13, 75501 Saku, Estonia

\begin{abstract}
The re-cultivation of abandoned areas creates weed control problems. The main problems in these areas are perennial weeds, such as Cirsium arvense L. but this perennial deep-rooted plant may have a beneficial effect on the physical properties of compacted soil. In order to study the effect of $C$. arvense's root system on soil properties, the field experiment and a survey of arable fields were conducted in Estonia. The soil bulk density and penetration resistance were measured from soils covered by $C$. arvense or spring barley (Hordeum vulgare L.) on compacted and un-compacted soil. The results showed significantly lower penetration resistance and bulk density underneath $C$. arvense than under barley in both the field experiment and a field survey on arable soils. The shoot mass of $C$. arvense was less affected than the shoot mass of barley by soil compaction and was caused by $C$. arvense's better ability to develop its root system in compacted soil. Wheat yield, on soils affected by $C$. arvense, was increased by $28 \%$ on loose soil and $37 \%$ on compacted soil. It may be concluded that in areas affected by deep-rooted weed species, such C. arvense, the soil's physical properties will improve at least in the first two years.
\end{abstract}

Key-words: soil, Cirsium arvense, barley, wheat, penetration resistance, bulk density, roots

\section{Introduction}

Agriculture is a threat to soil quality due to heavy use of the land for securing food for people and animals. The main threats to soil quality in a
European context are erosion, decline in organic matter, soil contamination, soil sealing, soil compaction, decline in soil biodiversity, salinization, floods and landslides. One third of the arable land in Estonia is affected by some kind of degradation (FAO 2000) and about $11 \%$ by soil compaction 


\section{AGRICULTURAL AND FOOD SCIENCE}

\section{Reintam, E. et al. Cirsium arvense on arable soils}

(van Lynden 2000). The area of Estonian arable land has decreased, since the re-establishment of the independence of Estonia in 1991, to $53 \%$ of the previous level (Astover et al. 2006).

The re-cultivation of abandoned areas creates weed control problems. Four to six years after the termination of cultivation Elytrigia repens L., Cirsium arvense L. and other perennial species become predominant in the fields. The presence of a large number of rhizomes and roots and a high weed seed density in the soil (Lauringson and Talgre 2003), creates a need for higher mechanical control of weeds in the initial re-cultivation years, especially if the land was not cultivated for a long time. C. arvense is a persistent weed that causes problems in crop fields, grasslands and pastures as well as on fallow and nature conservation areas in temperate regions of both hemispheres (Donald 1994). C. arvense grows on a variety of soil types. It does well on deep, well aerated, moist loam soils, but is known to grow in dry habitats and on sandy soils. It may also grow on stream banks, in meadows, and even in wet ditches, but it will not survive in saturated soil. It is intolerant of shade, requiring good light conditions for aggressive growth (Moore 1975). C. arvense has now become one of the severest perennial weed problems in organic agriculture in north European countries, particularly in crop rotations with a high proportion of cereals (Salonen et al. 2001, Graglia et al. 2006).

However, $C$. arvense has an extensive root system, which is able to grow as deep as $6.8 \mathrm{~m}$, but commonly the roots reach a depth of $1.5 \mathrm{~m}$ in oneyear old plants, and $2 \mathrm{~m}$ in two to ten year old plants (Nadeau 1989). The root weight of $C$. arvense averages $1100 \mathrm{~g} \mathrm{~m}^{-2}$ and decreases with depth, from 500 $\mathrm{g} \mathrm{m}^{-2}$ in the top $30 \mathrm{~cm}$, to $350 \mathrm{~g} \mathrm{~m}^{-2}$ in $31-60 \mathrm{~cm}$, and $250 \mathrm{~g} \mathrm{~m}^{-2}$ in 61-90 $\mathrm{cm}$ depth (Donald 1994). It has been established that more than 20 cultural plants species are able to sufficiently develop their root system in dense and strong soil (Materachera et al. 1991). That kind of penetration of plant roots into compacted soil has been described as a possible natural process, which may ameliorate compacted soil (Williams and Weil 2004). Plants modify soil structure mainly when their roots grow into the dense layers, then later die and decay leaving behind pores or channels that are termed biopores (Yunusa and Newton 2003).

The hypothesis of the current study was that $C$. arvense due to its vigorous root system may also be able to penetrate compacted soil and loosen it in which case there would be a substantial benefit from having $C$. arvense on fallow land. In order to study the hypothesis the field survey on arable fields with high level of $C$. arvense infestation was conducted to determine if $C$. arvense had changed the soil penetration resistance of fields affected by it. In order to study the effect of $C$. arvense in more controlled conditions and to find out the residual effect of $C$. arvense, the field experiment was established. The aims of the field experiment were complex investigations of the soil and C. arven$s e$. The main goals of the current study were to investigate: 1) changes in soil penetration resistance and bulk density due to compaction and C. arvense; 2) the mass and density of root and shoots of $C$. arvense due to compaction and 3) the residual effect of $C$. arvense growing on compacted soil on the development and yield of spring wheat (Triticum aestivum L.). Spring barley (Hordeum vulgare L.) growing on compacted and un-compacted soils were used as control treatments.

\section{Material and methods}

Data from field survey were collected from the fields of five Estonian counties in the year 1997. Data from field experiment were collected from the research field of the Estonian University of Life Sciences on a sandy loam surface Stagnic Luvisol at Tartu County in Eerika $\left(58^{\circ} 23^{\prime} \mathrm{N}, 26^{\circ} 44^{\prime} \mathrm{E}\right)$ in the years 2004-2006.

\section{Survey on the arable fields}

In order to study the effect of $C$. arvense growing on soil properties on arable fields, a survey was 
Vol. 17 (2008): 153-164.

conducted at six locations in five counties in Estonia. The locations under survey were Rõngu and Eerika in Tartu, Helme in Valga, Näsare in Viljandi, Kergu in Pärnu and Looritsa in Järva. Those fields in which $C$. arvense was present and had been abandoned for four years were selected to measure soil penetration resistance inside $C$. arvense colonies and in soil where $C$. arvense was not growing. The crops growing in the fields were oat (Avena sativa L.) in Rõngu, Helme and Kergu, spring wheat in Näsare and spring barley in Looritsa and Eerika.

The soil types of the six investigated locations during the field survey were the following in WRB 1998 classification (FAO 1998): Eerika - sandy loam Stagnic Luvisol, Rõngu - loamy Gleyi-Dystric Luvisol, Helme - loamy sand Dystric Luvisol, Näsare - sandy loam Stagnic Luvisol, Kergu - silty loam Calcaric Regosol and Looritsa - sandy Haplic Luvisol.

During the soil survey the soil penetration resistance, soil moisture content and shoot density and mass of $C$. arvense were investigated. No detailed investigations on soil density and other parameters were made as the goal of the study was to detect if there are some differences at all between areas with and without $C$. arvense in soil physical parameters. Penetration resistance for the field survey was measured to a depth of $40 \mathrm{~cm}$. From the same depths were taken samples to measure soil moisture content.

\section{Field experiments}

The field experiment was established in 2001. A 4.9 tonne, MTZ-82 tractor was used to compact the soil before sowing time in spring 2001, 2002, 2003, 2004 and 2005. Six repeated passes with a wheeled trailer loaded with 2.22 tonne on the front axle and 2.62 tonne on the rear axle (total load was 4.84 tonne) uniformly covered the entire experimental plot area. The inflation pressure in the wheels of the tractor was $150 \mathrm{kPa}$. Two compaction treatments were established on the experimental field. The area without special compaction served as the control. The compaction treatments were split into four replications (16 plots) and the size of each experimental plot was $12 \times 9 \mathrm{~m}\left(108 \mathrm{~m}^{2}\right)$. Drilling of barley (crosswise to compaction treatments) at a rate of 450 germinating seeds per $\mathrm{m}^{2}$ was conducted in the middle of May. No fertilizers and herbicides were used in the experiment. Each compaction treatment plot was split into deep-rooted species treatments (size of each plot $3 \times 9 \mathrm{~m}$ ) in 2004. $C$. arvense was planted with density of 16 plants per $\mathrm{m}^{2}$ in spring of 2004 to a $15 \mathrm{~cm}$ depth. Planted plants were approximately $10 \mathrm{~cm}$ high with at least $5 \mathrm{~cm}$ horizontal root fragment. Barley treatment served as a control. Both treatments were compacted again in spring of 2005. Special compaction was not made in 2006 and the wheat was sown (at the rate of 500 germinating seeds per $\mathrm{m}^{2}$ ) over the entire experiment area to establish the residual effect of $C$. arvense and barley. Every autumn (in September) the soil was ploughed to a depth of $21-22 \mathrm{~cm}$.

The surface soil type of the experiment area was a sandy loam Stagnic Luvisol in the WRB 1998 (FAO 1998) classification. Analysis of the genetic and diagnostic horizons indicated that the horizons of humus $(32 \mathrm{~cm})$, ferralic accumulation $(8 \mathrm{~cm})$, stagnic $(10 \mathrm{~cm})$ and argillic $(29 \mathrm{~cm})$ were found in the soil profile. The soil characteristics (at the beginning of experiment in 2001) of the humus horizon $(30 \mathrm{~cm})$ were: $\mathrm{C}_{\text {org }} 1.4 \%, \mathrm{~N}_{\text {tot }} 0.11 \%$, available K $164 \mathrm{mg} \mathrm{kg}^{-1}$, P $183 \mathrm{mg} \mathrm{kg}^{-1}$, Ca $674 \mathrm{mg}$ $\mathrm{kg}^{-1}, \mathrm{Mg} 101 \mathrm{mg} \mathrm{kg}{ }^{-1}, \mathrm{pH}_{\mathrm{KCl}} 6.2$, sand (2.0-0.02 $\mathrm{mm}) 67.9 \%$, silt $(0.02-0.002 \mathrm{~mm}) 22.9 \%$ and clay $(<0.002 \mathrm{~mm}) 9.2 \%$. The abrupt textural change started at $50 \mathrm{~cm}$ depth with $49 \%$ sand, $30 \%$ silt and $20 \%$ of clay. The investigated soil formed on bisequal-textured reddish-brown till and is sensitive to soil compaction. This type of soil covers $5.9 \%$ of the total area, and $15.1 \%$ of the arable land in Estonia, mostly in the south and the south-east (Reintam and Köster 2006).

\section{Field sampling}

The samples of soil and plants were taken in the earing phase of barley in growth stage $75-79$ by the numeric code description according to the $\mathrm{BBCH}$ 
Reintam, E. et al. Cirsium arvense on arable soils

(Biologische Bundesanstalt, Bundessortenamt and CHemical industry) Growth Scale of plants (Lancashire et al. 1991). Data regarding the botanical composition of the plant community were obtained from taking vegetation samples from a plot of $0.25 \mathrm{~m}^{2}(n=4)$. The types of plant community components (barley and different weed species) were determined, counted, measured and weighed. Root samples were taken using $1131 \mathrm{~cm}^{3}(\mathrm{~h}=15$ $\mathrm{cm}, \varnothing=9.8 \mathrm{~cm}$ ) steel cylinders in $15 \mathrm{~cm}$ layers down to $60 \mathrm{~cm}$ in 4 replications. The soil from the cylinders was weighed and the soil bulk density calculated before root washing on a $0.5 \mathrm{~mm}$ sieve. Penetration resistance was measured with a hand cone penetrometer (cone angle $60^{\circ}$, stick diameter $12 \mathrm{~mm}$ ) in every $5 \mathrm{~cm}$ layer down to $60 \mathrm{~cm}$ in six

Table 1. Soil moisture content $\left(\mathrm{g} \mathrm{kg}^{-1}\right)$ during field survey underneath of Cirsium arvense L. and spring barley (Hordeum vulgare L.) in 0-40 cm depth in the earing phase of barley (in middle of July). In parentheses is the standard error of the mean.

\section{Location Cirsium arvense L. Hordeum vulgare L.}

\begin{tabular}{lrr}
\hline Rõngu & $197(11)$ & $192(18)$ \\
Helme & $161(8)$ & $160(10)$ \\
Näsare & $196(5)$ & $193(7)$ \\
Kergu & $182(3)$ & $174(10)$ \\
Looritsa & $163(12)$ & $189(4)$ \\
Eerika & $211(17)$ & $204(13)$ \\
\hline
\end{tabular}

replications from every experimental plot. Samples for measuring soil moisture content were taken from the same layers. Soil moisture was measured both in the spring, after special compaction, and in summer at the same time as the soil penetration resistance measures. To find out the water content in the soil, the soil samples taken from the field (by $50 \mathrm{~cm}^{3}$ cylinders) were weighted and dried at $105^{\circ} \mathrm{C}$ to the constant weight and weighted again. After that the water content was calculated as follow:

moisture, $\%=\frac{W w-D w}{D w} \times 100$,

where $W w$ is soil wet weight and $D w$ is soil dry weight in grams.

Soil moisture content at compaction was $170-180 \mathrm{~g} \mathrm{~kg}^{-1}(-60$ to $-70 \mathrm{kPa})$ in 2004 and 2005. Soil moisture content in the earing phase of barley is presented in Tables 1 and 2 .

\section{Weather conditions}

In year 1997 more precipitations occurred in May and June and less in July and August (Table 3). The end of August was warmer as in most years. During the field experiment the rainiest year was 2004, when it was $475 \mathrm{~mm}$ precipitations during growing period (Table 3). In 2005 and 2006 only 282 and $161 \mathrm{~mm}$ of rain was recorded, respectively. More precipitation

Table 2. Soil moisture content $\left(\mathrm{g} \mathrm{kg}^{-1}\right)$ during field experiment underneath (2004-2005) and against the background (2006) of Cirsium arvense L. and spring barley (Hordeum vulgare L.) in the earing phase of barley (in middle of July). In parentheses is the standard error of the mean.

\begin{tabular}{|c|c|c|c|c|c|}
\hline \multirow{2}{*}{ Year } & \multirow{2}{*}{ Soil depth $(\mathrm{cm})$} & \multicolumn{2}{|c|}{ Cirsium arvense $\mathrm{L}$. } & \multicolumn{2}{|c|}{ Hordeum vulgare L. } \\
\hline & & Un-compacted & Compacted & Un-compacted & Compacted \\
\hline \multirow[t]{2}{*}{2004} & $0-30$ & $218(10)$ & 204(4) & $200(7)$ & $189(12)$ \\
\hline & $30-60$ & $160(2)$ & $166(9)$ & $151(8)$ & $148(11)$ \\
\hline \multirow[t]{2}{*}{2005} & $0-30$ & $91(4)$ & $82(7)$ & $150(12)$ & $142(5)$ \\
\hline & $30-60$ & $87(6)$ & $81(6)$ & $108(3)$ & $113(8)$ \\
\hline \multirow[t]{2}{*}{2006} & $0-30$ & $135(2)$ & $121(11)$ & $153(3)$ & $151(7)$ \\
\hline & $30-60$ & $93(5)$ & $91(6)$ & $99(9)$ & $91(5)$ \\
\hline
\end{tabular}


Vol. 17 (2008): 153-164.

occurred in June and August, less in July. Average air temperature was highest in August $\left(17.1^{\circ} \mathrm{C}\right)$ in 2004 and in July in 2005 and 2006.

\section{Statistics}

The three-way analysis of variance (ANOVA) was used to determine the impact of the trial factors based on the collected data. The factors were soil depth, compaction and plant species. The Fisher test was used to compare the differences between values and least significant differences (LSD) at significance $p<0.05$ detected and the significance between treatments estimated. The standard error of the mean was, for the presentation of the data in the figures, calculated. The program Statistica 7.0 was used for data analysis (StatSoft 2006).

\section{Results}

\section{Field survey}

The field survey on Estonian arable land affected by $C$. arvense, which have been abandoned for four years and than re-cultivated, revealed the loosening effect of $C$. arvense roots on compacted soil. Soil penetration resistance underneath $C$. arvense was lower in all investigated locations than under crops (Fig. 1). A significantly lower soil penetration resistance under $C$. arvense was found in Rõngu, Näsare and Kergu. However, no significantly higher moisture content was detected under $C$. arvense (Table 1). The averages for the mass of $C$. arvense shoots were $580 \mathrm{~g} \mathrm{~m}^{-2}$, with a density of shoots at $33 \mathrm{~m}^{-2}$ and a height $1.2 \mathrm{~m}$ (Table 4). There was about 7-8 C. arvense patches per hectare, except

Table 3. Weather conditions of experiment years (1997, 2004-2006) during spring barley (Hordeum vulgare L.) growing period.

\begin{tabular}{|c|c|c|c|c|c|c|c|c|}
\hline \multirow{2}{*}{$\begin{array}{l}\text { Months and } \\
\text { decades* }\end{array}$} & \multicolumn{4}{|c|}{ Precipitations (mm) } & \multicolumn{4}{|c|}{ Mean air temperature $\left({ }^{\circ} \mathrm{C}\right)$} \\
\hline & 1997 & 2004 & 2005 & 2006 & 1997 & 2004 & 2005 & 2006 \\
\hline \multicolumn{9}{|l|}{$\overline{\text { May }}$} \\
\hline I & 33.6 & 10.2 & 14.8 & 0.0 & 7.0 & 15.6 & 7.6 & 14.1 \\
\hline II & 5.1 & 4.0 & 52.8 & 16.4 & 11.8 & 7.2 & 9.8 & 10.8 \\
\hline III & 26.1 & 20.0 & 46.4 & 15.2 & 8.6 & 13.6 & 14.9 & 10.9 \\
\hline \multicolumn{9}{|l|}{ June } \\
\hline I & 3.5 & 46.6 & 17.8 & 36.8 & 15.7 & 13.4 & 12.4 & 11.5 \\
\hline II & 81.6 & 20.6 & 18.4 & 0.2 & 16.2 & 12.3 & 15.6 & 18.6 \\
\hline III & 30.5 & 143.4 & 18.0 & 10.0 & 16.7 & 14.5 & 15.3 & 18.7 \\
\hline \multicolumn{9}{|l|}{ July } \\
\hline I & 22.9 & 28.0 & 0.0 & 10.0 & 20.0 & 15.1 & 19.1 & 21.0 \\
\hline II & 2.6 & 20.0 & 3.0 & 0.0 & 16.1 & 15.8 & 21.2 & 18.2 \\
\hline III & 9.3 & 65.6 & 18.6 & 6.2 & 19.6 & 18.3 & 17.6 & 17.2 \\
\hline \multicolumn{9}{|l|}{ August } \\
\hline I & 11.4 & 3.2 & 75.8 & 13.6 & 20.6 & 20.0 & 17.4 & 17.0 \\
\hline II & 19.3 & 53.0 & 7.0 & 16.2 & 14.6 & 15.9 & 16.2 & 17.9 \\
\hline III & 0.0 & 34.4 & 9.6 & 36.4 & 21.2 & 13.7 & 16.1 & 16.2 \\
\hline
\end{tabular}

* Decade - ten day period of month 
Reintam, E. et al. Cirsium arvense on arable soils

Fig. 1. Soil penetration resistance depending on Cirsium arvense L. growing on six arable fields in Estonia: Rõngu - loamy Gleyi-Dystric Luvisol, Helme - loamy sand Dystric Luvisol, Näsare - sandy loam Stagnic Luvisol, Kergu - silty loam Calcaric Regosol and Looritsa - sandy Haplic Luvisol, Eerika - sandy loam Stagnic Luvisol. An average of top $40 \mathrm{~cm}$ soil layer. Box: mean \pm standard error. Whisker: mean \pm 0.95 confidence interval.

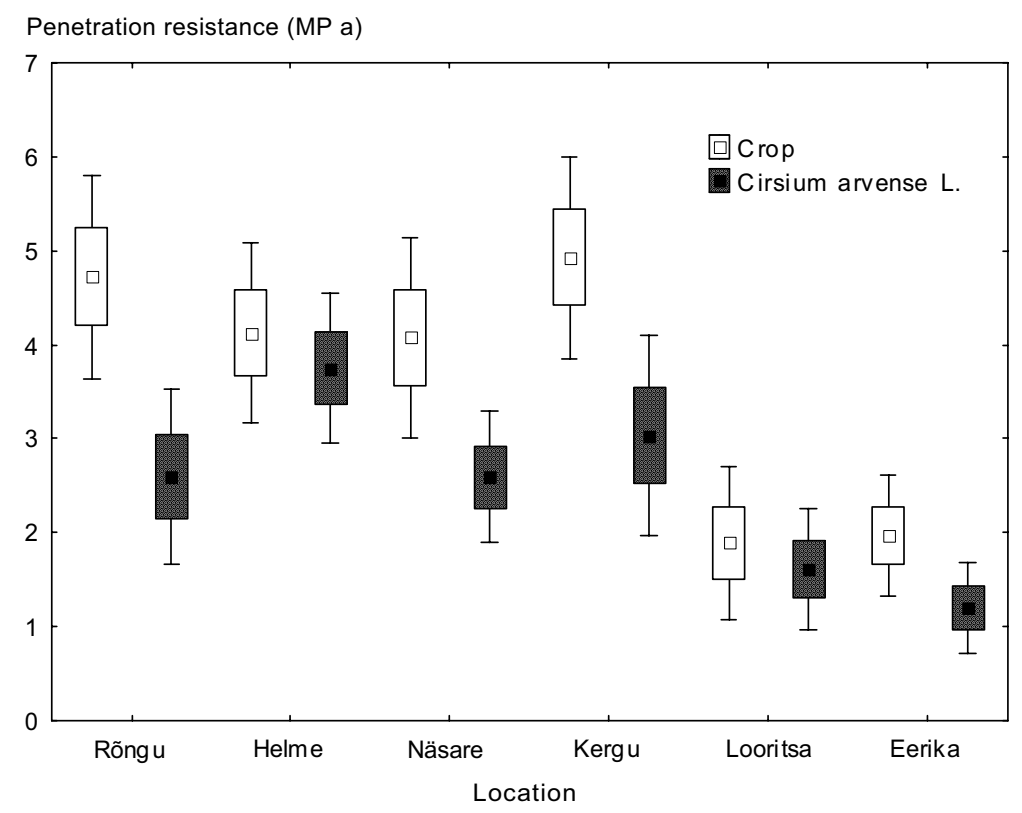

Table 4. Cirsium arvense L. shoots density (plants $\mathrm{m}^{-2}$ ) and dry weight $\left(\mathrm{g} \mathrm{m}^{-2}\right)$ in patch on six arable field of Estonia: Rõngu - loamy Gleyi-Dystric Luvisol, Helme - loamy sand Dystric Luvisol, Näsare - sandy loam Stagnic Luvisol, Kergu - silty loam Calcaric Regosol and Looritsa - sandy Haplic Luvisol, Eerika - sandy loam Stagnic Luvisol. In parentheses is the standard error of the mean.

\begin{tabular}{lcc}
\hline Location & $\begin{array}{c}\text { Density } \\
\left(\text { plants } \mathrm{m}^{-2}\right)\end{array}$ & $\begin{array}{c}\text { Shoot weight } \\
\left(\mathrm{g} \mathrm{m}^{-2}\right)\end{array}$ \\
\hline Rõngu & $35(12)$ & $670(108)$ \\
Helme & $27(6)$ & $464(67)$ \\
Näsare & $43(19)$ & $632(105)$ \\
Kergu & $21(9)$ & $568(130)$ \\
Looritsa & $44(12)$ & $617(187)$ \\
Eerika & $29(7)$ & $534(101)$ \\
\hline
\end{tabular}

in Helme, where the field was totally covered with patches and only some $30-56 \mathrm{~m}^{2}$ areas were without $C$. arvense. The next most widespread weed species after $C$. arvense were Sonchus arvensis L., Elytrigia repens L., Artemisia vulgaris L. and also Tussilago farfara $\mathrm{L}$.

\section{Field experiment}

\section{Direct effect}

The results of the field experiment revealed soil compaction had a harmful effect on spring barley and $C$. arvense above ground mass in the first year, 2004 (Fig. 2a). C. arvense increased its shoot mass in the second year, 2005, and the mass was twice as much on compacted than on un-compacted soil. Compaction, however, had only a negative effect on barley shoots decreasing their mass by $50 \%$ in the relatively dry year of 2005 .

The shoot density of $C$. arvense was greater by 30 plants per $\mathrm{m}^{2}$ on un-compacted soil in the first year than on compacted soil (Fig. 3a). The results the next year were the exact opposite, 30 plants per $\mathrm{m}^{2}$ more on compacted soil. Shoot density of spring barley was 1.6 times higher in year 2004, than in year 2005 (Fig. 3b). Barley shoot density, however, did not decrease significantly in year 2005 as a result of compaction.

The root mass of barley decreased rapidly as soil bulk density and depth increased (Fig. 4b). The roots in compacted soil concentrated more in the soil surface horizon $(15 \mathrm{~cm})$ while almost no roots 
Vol. 17 (2008): 153-164.
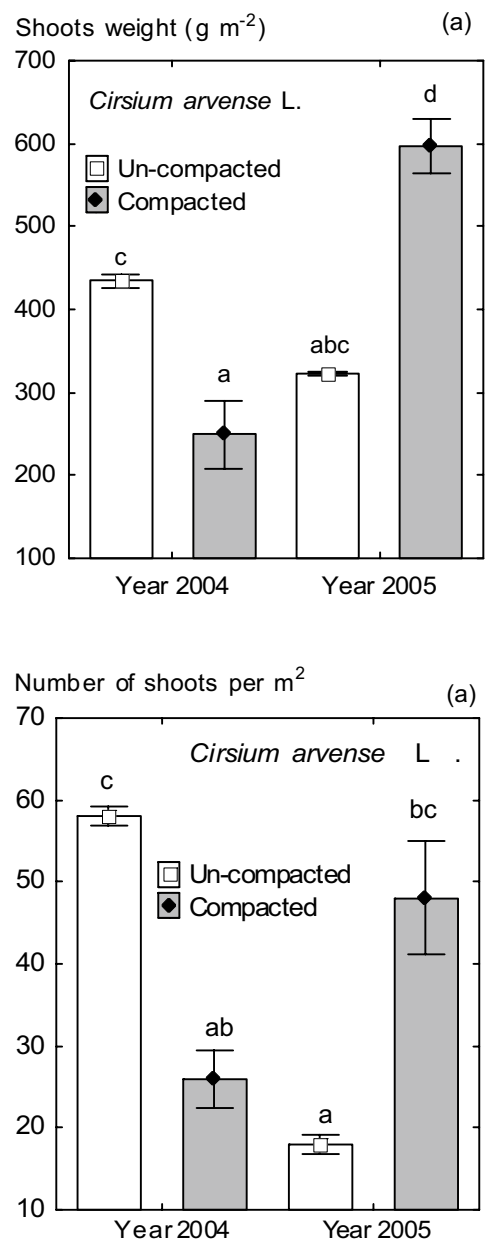

Root weight $\left(\mathrm{g} \mathrm{m}^{-2}\right)$

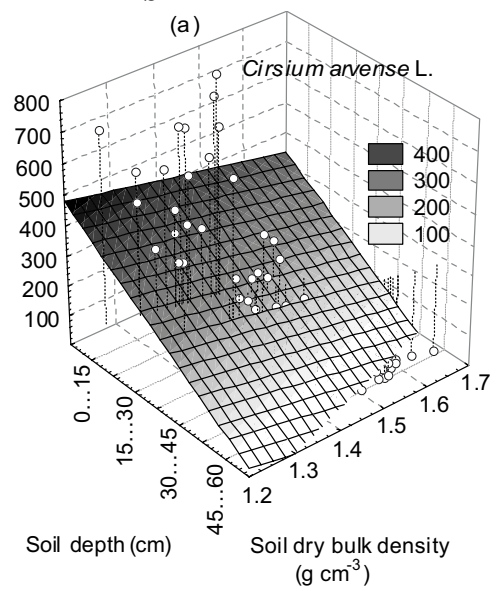

(b)

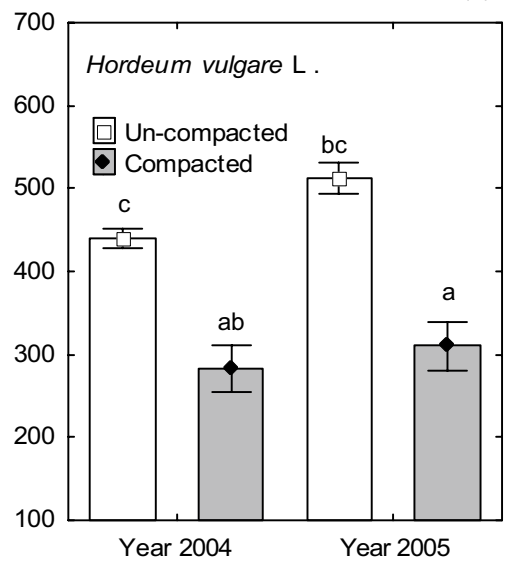

(b)

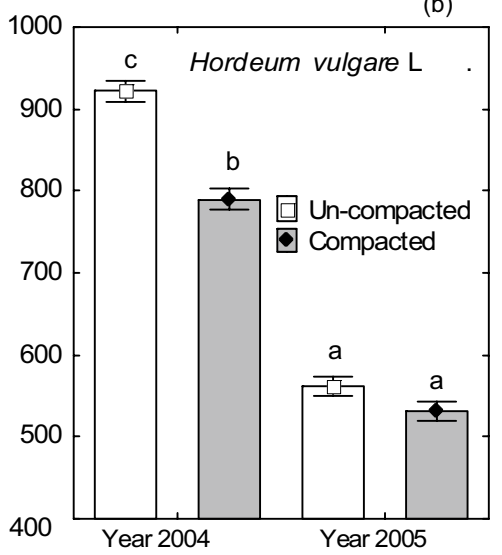

Root weight $\left(\mathrm{g} \mathrm{m}^{-2}\right)$

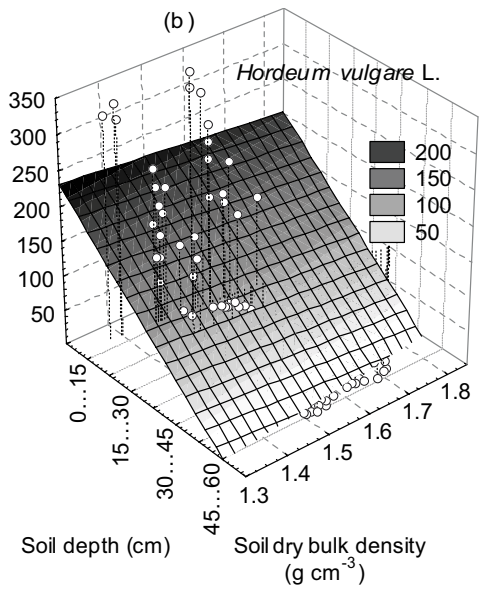

Fig. 2. The shoots dry weight $\left(\mathrm{g} \mathrm{m}^{-2}\right)$ of Cirsium arvense $\mathrm{L}$. (a) and spring barley (Hordeum vulgare L.) (b) depending on soil compaction. Bars denote the standard error of the mean. Means with the same letter do not differ according to Fisher's LSD test at $p>0.05$.

Fig. 3. The shoots density (plants $\mathrm{m}^{-2}$ ) of Cirsium arvense L. (a) and spring barley (Hordeum vulgare L.) (b) depending on soil compaction. Bars denote the standard error of the mean. Means with the same letter do not differ according to Fisher's LSD test at $p>0.05$.

Fig. 4. Predicted and real values of root mass of Cirsium arvense L. (a) and spring barley (Hordeum vulgare L.) (b) depending on soil bulk density and soil depth. Equation to the root weight of $C$. arvense $\mathrm{L} .: \mathrm{g} \mathrm{m}^{-2}=$ 12189.0-296.5x-112.9y; barley: $\mathrm{g} \mathrm{m}^{-2}=6888.5-53.5 \mathrm{x}-65.5 \mathrm{y}$ 
Reintam, E. et al. Cirsium arvense on arable soils
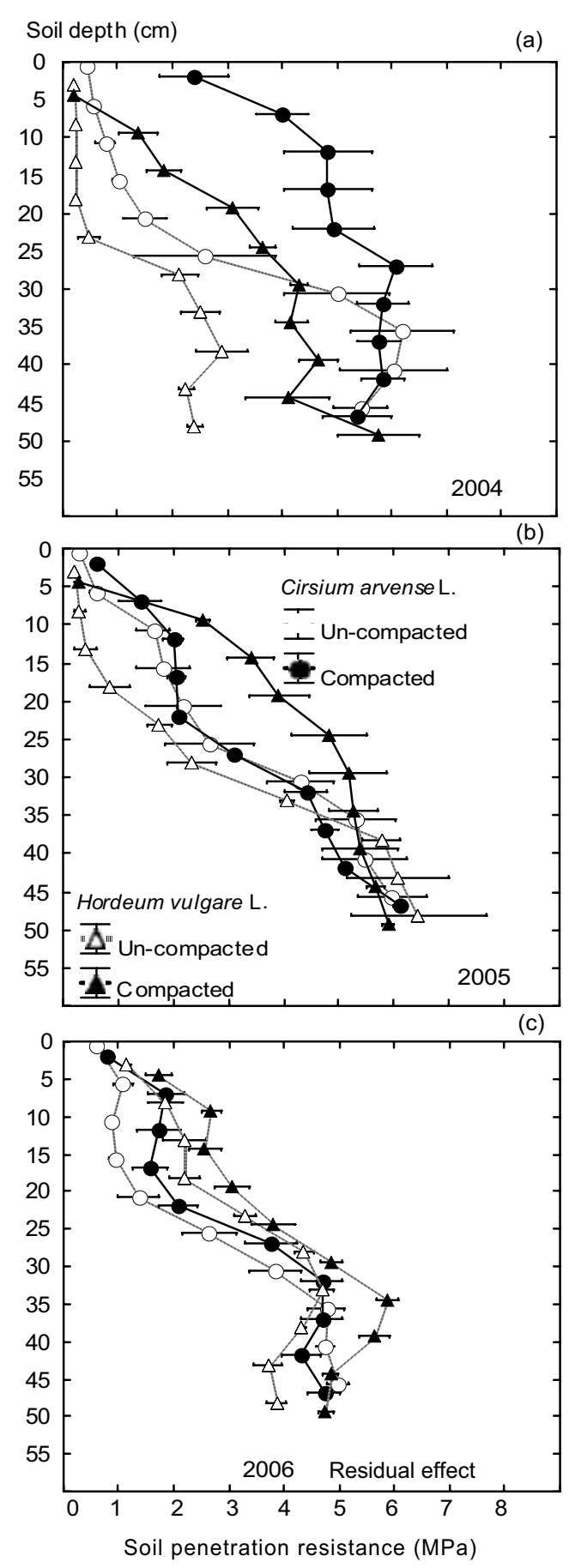

Fig. 5. Direct effect (a, b) and residual effect (c) of soil compaction and Cirsium arvense L. and spring barley (Hordeum vulgare $\mathrm{L}$.) growing on soil penetration resistance (MPa). Bars denote standard error of the mean. were detected at the soil depth of $60 \mathrm{~cm}$. The opposite occurred to the root mass of $C$. arven$s e$, which in compacted soil increased in depths 15-30 cm (Fig. 4a). The root mass of $C$. arvense was, in comparison with the root mass of barley, 2.8 times greater in upper soil layers $(15 \mathrm{~cm})$ and 2 times greater in deeper layers.

The results in the field experiment confirm the hypothesis that $C$. arvense roots are able to penetrate and loosen compacted soil. Soil penetration resistance, in the first year after planting with direct compaction, was higher underneath C. arvense than under barley in both compaction treatments (Fig. 5a). The year afterwards, C. arvense had significantly reduced soil resistance in the upper $30 \mathrm{~cm}$ soil layer (Fig. 5b) even if the moisture content at the moment of measure was lower than in year 2004 (Table 2). There was a trend of soil resistance reduction in the deeper soil layers underneath $C$. arvense, but the differences were not statistically significant.

Compaction increased soil dry bulk density from 1.4 to $1.58 \mathrm{~g} \mathrm{~cm}^{-3}$ and from 1.52 to $1.56 \mathrm{~g}$ $\mathrm{cm}^{-3}$ by barley cultivation in topsoil $(0-30 \mathrm{~cm})$ as well as in subsoil $(30-50 \mathrm{~cm})$, respectively, in year 2004 (Fig. 6b). Fifth year continuous compaction increased soil bulk density especially in subsoil by barley cultivation. However, un$\operatorname{der} C$. arvense the soil bulk density remained lower in topsoil and higher in subsoil in the first year (Fig. 1a). Second year $C$. arvense growth increased bulk density in topsoil and decreased in subsoil.

\section{Residual effect}

Wheat grown in rotation a year after $C$. arvense showed greater shoot mass and density formation than after barley monoculture (Fig. 7). The differences were a significant increase on the previous year's compacted soil, when the shoot mass of wheat was 1.5 times higher against the background of $C$. arvense than against the background of barley (Fig. 7a); also the shoot mass of wheat was greater on un-compacted soil after $C$. arvense than after barley. Wheat shoot density was 2 times greater following $C$. arvense on compacted and un-compacted soil (Fig. 7b) whereas there 


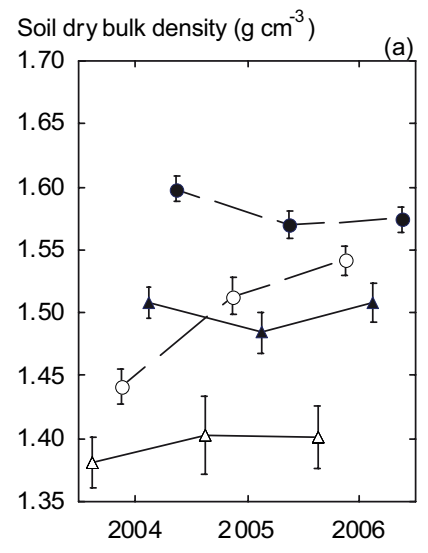

Cirsium arvense $\mathrm{L}$.

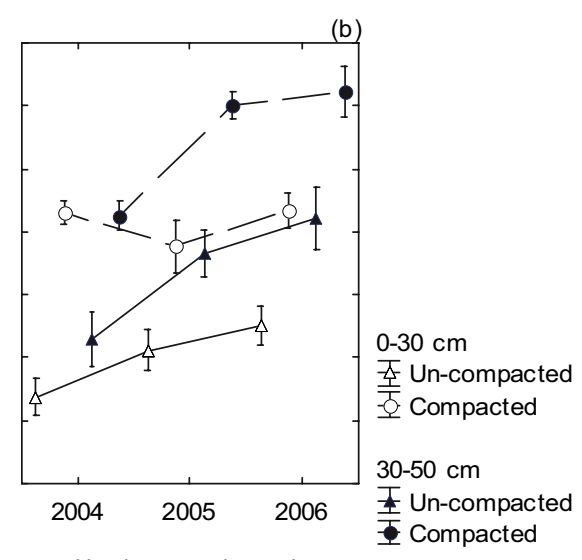

Hordeum vulgare L.

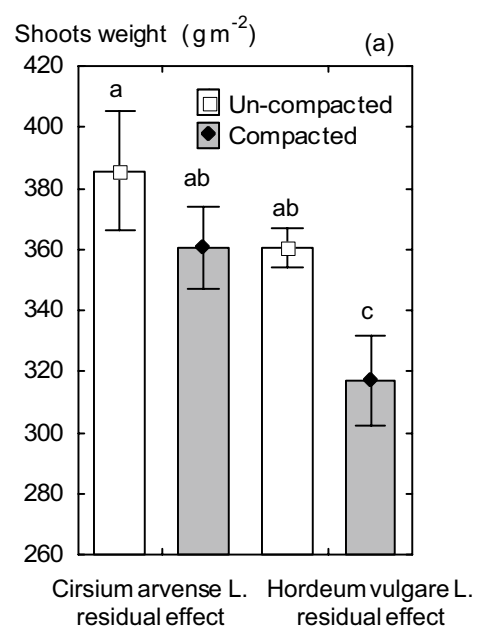

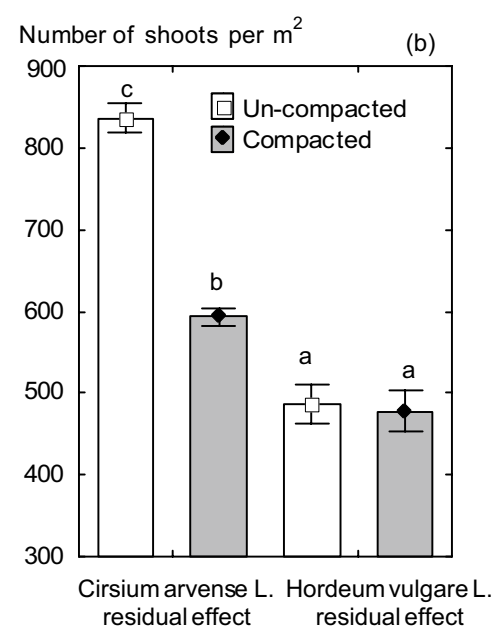

Fig. 6. Direct effect (2004-2005) and residual effect (2006) of soil compaction and Cirsium arvense L. (a) and spring barley (Hordeum vulgare L.) (b) growing on soil dry bulk density ( $\mathrm{g}$ $\mathrm{cm}^{-3}$ ). Bars denote standard error of the mean.
Fig. 7. Residual effect of Cirsium arvense L. and spring barley (Hordeum vulgare L.) on spring wheat (Triticum aestivum L.) shoots dry weight (a) and density (b). Bars denote the standard error of the mean. Means with the same letter do not differ according to Fisher's LSD test at $p>0.05$. were no significant differences in wheat shoot density between compacted and un-compacted soil after barley.

The residual effect on the grain yield of wheat differed far more than shoot mass between the two treatments (Table 5). Grain yield varied from $154 \mathrm{~g}$ $\mathrm{m}^{-2}$ to $248 \mathrm{~g} \mathrm{~m}^{-2}$ after barley and from $247 \mathrm{~g} \mathrm{~m}^{-2}$ to $345 \mathrm{~g} \mathrm{~m}^{-2}$ following C. arvense on compacted and un-compacted soil, respectively. There were less than 0.2 C. arvense plants per $\mathrm{m}^{2}$ in year 2006 and no negative impact on wheat yield was detected.

Measures of soil penetration resistance in the year following C. arvense and barley showed low-
Table 5. Residual effect of Cirsium arvense L., spring barley (Hordeum vulgare L.) and soil compaction on wheat (Triticum aestivum L.) grain yield (air dry).

\begin{tabular}{lc}
\hline Treatment & $\begin{array}{c}\text { Grain yield } \\
\left(\mathrm{g} \mathrm{m}^{-2}\right)\end{array}$ \\
\hline
\end{tabular}

Residual effect of C. arvense

$\begin{array}{lr}\text { un-compacted } & 345 \mathrm{a}^{2} \\ \text { compacted } & 247 \mathrm{ab} \\ \text { un-compacted } & 248 \mathrm{ab} \\ \text { compacted } & 154 \mathrm{c}\end{array}$

$\mathrm{LSD}_{0.05}{ }^{1}$ 124

${ }^{1}$ Least significant difference at $p<0.05$

${ }^{2}$ Means with the same letter do not differ according to Fisher's LSD test at $p>0.05$ 


\section{AGRICULTURAL AND FOOD SCIENCE}

\section{Reintam, E. et al. Cirsium arvense on arable soils}

er results in soil planted previously by $C$. arvense, in both the topsoil and the subsoil (Fig. 5c). Soil penetration resistance after $C$. arvense in topsoil was $2 \mathrm{MPa}$ and $1.5 \mathrm{MPa}$ lower in topsoil and subsoil, respectively, than after barley. Due to the very dry season (Table 3 ), the values of bulk density were higher or almost the same in 2006 as in year 2005 (Fig. 6, 2006). However, soil bulk density remained lower against the background of $C$. arvense than barley.

\section{Discussion}

The loosening effect of compacted soil by $C$. arvense growing was directly connected with its root system (more than $1000 \mathrm{~g} \mathrm{~m}^{-2}$ ) and this effect while evident in the first year (2004) of $C$. arvense, was especially evident in the second year (2005). The root system of $C$. arvense can be extensive according to the literature, growing horizontally as much as $6 \mathrm{~m}$ in one season. Most patches spread at the rate of 1-2 m per year (Amor and Harris 1975). Roots of young C. arvense plants can grow rapidly, according to Nadeau and Vanden Born (1989) whose research indicated growth rates in the first 13 weeks of up to $1 \mathrm{~cm}$ per day; and after just 18 weeks, plants averaged 26 aboveground shoots, 154 underground shoots, and $111 \mathrm{~m}$ of roots. There were, in this study, more $C$. arvense shoots on compacted soil in the second year of growing. It indicates that on compacted soil C. arvense was developing more shoots than on un-compacted soil and also root analyses showed better root development and higher mass in compacted than un-compacted soil.

At the same time $C$. arvense does not tolerate strong direct compaction. Soil compaction, in an earlier study by a 17 tonne tractor in six passes decreased the shoot weight of naturally developed $C$. arvense by up to $50 \%$, but did not totally destroy the plant (Reintam 2000). Newly planted C. arvense developed shoots for the following spring, at a density of $55 \mathrm{~m}^{-2}$ on un-compacted and 88 $\mathrm{m}^{-2}$ on heavily compacted soil (Kuht and Reintam 2001). Although a tractor with a lower weight (4.9 tonne) was used in the current experiment, the development of $C$. arvense shoots was similar to the earlier study. Donald (1994) reported that shoot density and root growth are closely correlated: areas with highest shoot density also have the highest underlying root biomass and the highest density of adventitious root buds, and also deeper roots. The most extensive root growth occurs on moist clay whereas growth is reduced on excessively wet soils, and on droughty soils including sand, gravel, and hard-pans (Donald 1994). One explanation for there being more roots in compacted soil compared to un-compacted is that the soil water holding capacity of the former is closer to clay soils and the most extensive root growth occurs in moist clay.

However, even if $C$. arvense does not tolerate hard-pans it was able to spread its roots in compacted soil since the soil bulk density and penetration resistance in compacted soil were still probably within the limit of tolerance of $C$. arvense. Most plant roots can not penetrate a soil density in excess of $1.9 \mathrm{~g} \mathrm{~cm}^{-3}$ and when the density is more than $2.0 \mathrm{~g} \mathrm{~cm}^{-3}$ the plants are not able to use the soil water (Konoplev, 1966).

One-time cutting of $C$. arvense, at the same time as the barley harvesting in August, was another factor that led to an increase in C. arvense's density. Grekul and Bork (2007) discovered that one-time mowing failed to provide long-term control of $C$. arvense, and actually increased shoot densities. Cutting stimulated the growth of $C$. arvense shoots most likely from the release of dormant adventitious root buds, and led to a marked increase in C. arvense biomass by the second year when accompanied by fertilization.

Survey in arable fields revealed that soil penetration resistance was lower only underneath $C$. arvense patches because most $C$. arvense roots can be found directly below the above-ground shoots, with little extension beyond the border of a patch (Donald 1994). However, the grain yield at the centre of dense $C$. arvense patches can range from $28-71 \%$ of the yield in adjacent weed-free plots (McLennan et al. 1991). The same was established during this survey in Estonian arable fields. 
Vol. 17 (2008): 153-164.

The clones on most investigated fields were formed by vegetative spreading but also by seeds. The expansion by seeds was evident in Helme, where $C$. arvense covered almost all the territory of the field and no individual patches were detected, oat density was sparse or non-existent. Seeds play an important role in the infestation of new fields previously free of $C$. arvense. Graglia et al. (2006) found that an extensive root system and the ability to form new aerial shoots result in dense patches only a few years after establishment. The spread of $C$. arvense by seeds was especially evident in the second half of 1990s in Estonia, when at the end of August the air was full of $C$. arvense plume. During that time C. arven$s e$ was called "Estonian cotton" due to its massive spread on fallow land.

The soil loosening effect of $C$. arvense roots is connected with the formation of biopores and organic matter after the death of living roots. The biopores formed from plant roots may be more stabile than biopores formed by earthworms (Mc Kenzie and Dexter 1988). Blackwell et al. (1990) detected that biopores formed from lucerne roots that have a diameter over $4 \mathrm{~mm}$ can tolerate more than $200 \mathrm{kPa}$ pressures. Hirth et al. (1997) found, however, that only $6 \%$ of the roots of ryegrass that were deflected sideways, met with holes in the compacted subsoil. The number of roots that met with holes filled with either casts or soil was not significantly different from the number of roots that met with empty holes.

Dead plant roots also increase the content of organic matter in soil and with that the resistance to the compaction increases. The increase of organic matter up to $5 \mathrm{~g} \mathrm{~kg}^{-1}$ in clay soils decreased soil bulk density by $0.06 \mathrm{~g} \mathrm{~cm}^{-3}$ (Quiroga et al. 2000). The root weight of $C$. arvense, in the current study, ranged between $300-400 \mathrm{~g} \mathrm{~m}^{-2}$ in the top $30 \mathrm{~cm}$ soil layer, and between $100-200 \mathrm{~g} \mathrm{~m}^{-2}$ in deeper soil. The root mass of barley varied between $100-150 \mathrm{~g} \mathrm{~m}^{-2}$ in topsoil and less than 50 $\mathrm{g} \mathrm{m}^{-2}$ in subsoil (Fig. 4). This showed that C. arvense left more organic matter in the soil than barley.

\section{Conclusion}

The results revealed significantly lower soil penetration resistance and bulk density underneath $C$. arvense than under crops in Estonian soils affected by $C$. arvense over four years. $C$. arvense tolerated better soil compaction and its shoot and root mass was less affected by soil compaction than was the shoot and root mass of barley. Due to the influence of $C$. arvense roots, soil penetration resistance and soil bulk density were lower in un-compacted and compacted soil under $C$. arvense than under crops. Wheat yield was higher after $C$. arvense against the backdrop of both compaction treatments due to the lower soil penetration resistance and bulk density in these treatments. The conclusion may be drawn that in areas affected by deep-rooted weed species, such as $C$. arvense, soil physical properties may improve in already the first two years. How much $C$. arvense can we tolerate on field and how much C. arvense we need to improve soil characteristics needs further investigations.

Acknowledgments. This research was supported by Estonian Science Foundation grant No 5418 and 7622. The English correction of the paper was made by Marcus Denton from LLC Derettens.

\section{References}

Amor, R.L. \& Harris R.V. 1974. Distribution and seed production of Cirsium arvense (L.) Scop. in Victoria, Australia. Weed Research 14:317-323.

Astover, A., Roostalu, H., Lauringson, E., Lemetti, I., Selge, A., Talgre, L., Vasiliev, N., Mõtte, M., Tõrra, T. \& Penu, P. 2006. Changes in agricultural land use and in plant nutrient balances of arable soils in Estonia. Archives of Agronomy and Soil Sciences 52: 223-231.

Blackwell, P.S., Green, T.W. \& Mason, W.K. 1990. Responses of biopore channels from roots to compression by vertical stress. Soil Science Society of America Journal 54: 1088-1091.

Donald, W.W. 1994. The biology of Canada thistle (Cirsium arvense). Reviews of Weed Science 6: 77-101.

FAO, ISSS, ISRIC 1998. World reference base for soil resources. World Soil Resources Rep. 84, Rome.

FAO 2000. Soil and terrain database, soil degradation status and soil vulnerability assessment for Central 


\section{AGRICULTURAL AND FOOD SCIENCE}

\section{Reintam, E. et al. Cirsium arvense on arable soils}

and Eastern Europe. FAO land and water digital media series.

Graglia, E., Melander, B. \& Jensen, R.K. 2006. Mechanical and cultural strategies to control Cirsium arvense in organic arable cropping systems. Weed Research 46: 304-312.

Grekul, C.W. \& Bork, E.W. 2007. Fertilization augments Canada thistle (Cirsium arvense L. Scop) control in temperate pastures with herbicides. Crop protection 26: 668-676.

Hirth, J.R., McKenzie, B.M. \& Tisdall, J.M. 1997. Do the roots of perennial ryegrass elongate to biopores filled with the cast of endogeic earthworms? Soil Biology and Biochemistry 29: 529-531.

Konoplev, V.P. 1966. Reaktsija kulturnõh rastenij na uplotnenie potchvy. Selskoje hozjaistvo za rubezhom, No 2. (in Russian)

Kuht, J. \& Reintam, E. 2001. The impact of deep-rooted plants on the qualities of compacted soils. In: D. E. Stott, R.H. Mohtar \& G.C. Steinhardt (eds). Sustaining the Global Farm. Selected papers from the 10th International Soil Conservation Organization Meeting held May 24-29, 1999, Purdue University, USDA-ARS NSERL, pp. 632-636.

Lancashire, P., Bleiholder, H., v.d. Boom, T.P.L., Strauss, R., Weber, E. \& Witzenberger, A. 1991. A uniform decimal code for growth stages of crops and weeds. Annals of Applied Biology 119: 561-601.

Lauringson, E. \& Talgre, L. 2003. Problems of abandoned fields. Agronomy Research 1: 63-67.

Materachera, S.A., Dexter, A.R. \& Alston, A.M. 1991. Penetration of very strong soils by seedling roots of different plant species. Plant and Soil 135: 31-41.

Mc Kenzie, B.M. \& Dexter, A.R. 1988. Axial pressure generated by earthworm Aporrectodea rosea. Biology and Fertility of Soil 5: 323-327.
McLennan, B.R., Ashford, R. \& Devine, M.D. 1991. Cirsium arvense (L.) Scop. Competition with winter wheat (Triticum aestivum L.). Weed Research 31: 409-415.

Moore, R.J. 1975. The biology of Canadian weeds. 13. Cirsium arvense (L.) Scop. Canadian Journal of Plant Science 55: 1033-1048.

Nadeau, L.B. and W.H. Vanden Born. 1989. The root system of Canada thistle. Canadian Journal of Plant Science 69:1199-1206.

Quiroga, A.R., Buschiazzo, D.E. \& Peinemann, N. 2000 Soil compaction is related to management practices in the semi-arid Argentina pampas. Soil \& Tillage Research 52: 21-28.

Reintam, E. 2000. Umbrohud kultuurökosüsteemis sõltuvalt muldadest ja mulla tallamisest. /Weeds in agroecosystem depending on soils and soil compaction. MSc. Thesis. 98 pp. (in Estonian with English abstract)

Reintam, E. \& Köster, T. 2006. The role of chemical indicators to correlate some Estonian soils with WRB and Soil Taxonomy criteria. Geoderma 136: 199-209.

Salonen, J., Hyvönen, T. \& Jalli, H. 2001. Weed flora in organically grown spring cereals in Finland. Agricultural and Food Science in Finland 10: 231-242.

StatSoft (2006) STATISTICA for Windows, Version 7.0. StatSoft, Tulsa, OK, USA.

van Lynden G.W.J. 2000. Soil degradation in central and eastern Europe. The assessment of the status of human-induced degradation. FAO Report 2000/05. FAO and ISRIC.

Williams, S.M. \& Weil, R.R. 2004. Crop cover root channels may alleviate soil compaction effects on soybean crop. Soil Science Society of America Journal 68: 1403-1409.

Yunusa, I.A.M. \& Newton, P.J. 2003. Plants for amelioration of subsoil constraints and hydrobiological control: the primer-plant concept. Plant and Soil 257: 261-281. 